\title{
Historical GIS: mapping the Bucharest geographies of the pre-socialist industry
}

\author{
Gabriel Simion*, Alina Mareci, Florin Zaharia, Radu Dumitru
}

University of Bucharest, Romania

This article aims to map the manner in which the first industrial units crystalized in Bucharest and their subsequent dynamic. Another phenomenon considered was the way industrial sites grew and propagated and how the first industrial clusters formed, thus amplifying the functional variety of the city. The analysis was undertaken using Historical GIS, which allowed to integrate elements of industrial history with the location of the most important industrial objectives. Working in GIS meant creating a database with the existing factories in Bucharest, but also those that had existed in different periods. Integrating the historical with the spatial information about industry in Bucharest was preceded by thorough preparations, which included geo-referencing sources (city plans and old maps) and rectifying them. This research intends to serve as an example of how integrating past and present spatial data allows for the analysis of an already concluded phenomenon and also explains why certain present elements got to their current state..

\section{Key Words: historical GIS, GIS dataset, Bucharest.}

Article Info: Received: September 5, 2016; Revised: October 24, 2016; Accepted: November 15, 2016; Online: November 30, 2016.

\section{Introduction}

The spatial evolution of cities starting with the ending of the 19th century and the beginning of the 20th is closely connected to their industrial development. The functional zoning of the city, its transport network, greater population concentrations, as well as its spatial evolution tendencies are direct results of industrial transition. The emergence of an industrial area stimulates the concentration of human and material resources to ensure its viability. This concentration, is turn, creates flows of goods and human capital that support the

\footnotetext{
* Corresponding author

Address: University of Bucharest, Faculty of Geography, 1 Nicolae Balcescu Avenue, 010041, Bucharest, Romania.

Phone: +40213153074|Email: gabriel.simion@geo.unibuc.ro
} 
development of infrastructure, residential mobility, and implicitly other changes to the area's morphology and functionality. In this perspective it is necessary to map the industrial transition in order to understand its current urban planning context.

When exploring the industrial histories of the cities, it quickly became obvious that is required a database that would show the location of an industrial unit as well as the moment when it appeared, was necessary. This approach, located at a converging point between history and geography, can be easily done when using historical GIS (Holdsworth, 2003). Historical GIS comes to put together elements of history, historical geography, and spatial and digital history (Knowles, 2008) to provide a better visualising and understanding of spatial problematics from the past. This type of studies need to complement the geographical research with a capacity to contextualize and interpret historical sources (Knowles, 2002). A temporal analysis of the industrial phenomenon required a careful investigation of numerous and heterogeneous historical sources. Historical sources about industrial past also involved finding a way to facilitate the understating of historic information that had a spatial aspect to it. This information is often problematic to interpret and may cause difficulties, as it originates from a variety of sources. It might come from scale maps, cartographic styles, with different detail levels or accuracy, city plans, photos, census information of territories, etc. (Siebert, 2000). Historical GIS allowed an integrated approach of the spatial - temporal dimensions of city industry that are identified through the above-mentioned sources.

Historical GIS facilitates the understanding of such features that take place throughout different decades due to its capacity to integrate the two dimensions of this phenomenon: its temporality and its location but also thanks to its functions of simplified visualization of the information (MacEachren et al.,1999). Historical GIS started being used in history and historical geography studies at the beginning of the 2000s (Gregory \& Healey ,2007), and had a major impact on their results. The quantitative trend of studies in this fields allowed the use of modern techniques of analysis, visualization and representation of spatial data. Greogory \& Healey (2007) analysed the issue of using GIS in the above mentioned areas and evaluated the way in which it changed the research perspectives of history and historical geography.

Knowles \& Healey (2006) constructed a GIS based analysis of the steel industry in Pennsylvania where the dual spatial-temporal perspective, based on researching a series of hypothesis including: the moment when fossil fuel consuming technologies appeared, the way in which transport costs affected iron prices and the pre-war geographical segmentation of steel industry markets, lead to complex and dynamic models of regional economic development. Historical GIS captures the territorial features of a given time period and the relations established between the components of a territorial system. Based on this type of analysis Gregory (2002) explains how Historical GIS can encapsulate the temporal dynamic of territorial systems.

The applicative studies in Historical GIS are supplemented by debates regarding GIS's role in different fields (Healey \& Stamp, 2000; Greogory, 2002; Greogory et. al 2002; Southall, 2006; Maceachren et. al, 2010 \& Siebert, 2010). Wright et al. (1997) explains how the dual approach of GIS is necessary both as 
a tool for several research branches but also as a standalone science. Imagine a study about the evolution of the industrial landscape in Bucharest without GIS. The quantitative side would be completely lacking and understanding past contexts would be limited. Analysis themselves would be scarcer and would focus on a much more descriptive dimension of industrial activities existing throughout time. A detailed mapping of different time periods allowed for a comparative approach and extrapolation of conclusions about industrial increase in a specific year, location or relocation of specific industrial activities as well as clustering or isolation of industrial sites.

Within the present study, Historical GIS should be understood as a useful tool in addressing the information obtained from the cartographic materials and field mapping which had as a final goal inventorying and tracking the industrial sites from the pre-socialist period in Bucharest. The article analyses the manner in which the location, diffusion and industrial development occurred, as well as how spatial forms evolved in time, emphasized by concentrations or dispersions of industrial activities, of development axis or peripheral positions. The authors explain how the data bases with different temporality were created, how the information were extracted from the cartographic materials and hoe they were completed with other historical data. By introducing these sources in Historical GIS which enables the representation, analysis and visualization of inventoried data allowed for a snapshot of the industrial transition in Bucharest from the end of the 19th century to the beginning of the 20th.

\section{Creating the GIS databases}

The analyses was done in Historical GIS in order to integrate aspects related to the industrial past and location of the industrial objectives and, especially how the grows and diffusion of industrial sites, the formation of the first industrial clusters which amplified the functional variety of the city. Historical GIS allowed us in the same time, to obtain a complete analysis based on its visualisation software. The study was done in a GIS software and implied the creation of a data base of the factories that function in Bucharest as well as those that existed during its industrial past. Integrating different historical and spatial information had to be predate by a process that included geo-referencing sources (city plans, old maps) and rectifying them.

The Authors used multiple documentation sources, starting with old city plans of Bucharest, which contain names of factories, monographies and other studies about the city. The most representative books include: Istoria Bucureștilor din cele mai vechi timpuri până în zilele noastre / The History on Bucharest from the oldest of times to our present day by C.C. Giurescu (1966); the selfwritten essay of the $\mathrm{PhD}$ thesis Geografia industriei Municipiului București / The Industrial History of Bucharest by M. C. Herbst (1971); Evoluția geografică a unui oraș București / The Geographical Evolution of the City of Bucharest by Vintilă Mihăilescu (2003); Semicentenarul 1881-1931 - Istoricul desvoltării tecnice în România / The 1881-1931 Semicentenary - The History of Technical Development in Romania, volumes II and III, from 1931, edited by the Romanian Politechnical Society. 
Aside from the books mentioned above, which contain general aspects about Bucharest and elements of industrial geography, the authors also used monographies of factories such as Uzina Vulcan, of the Bucharest Abattoir, the RATB (The Autonomous Transportation Enterprise of Bucharest) Monography, The History of Transporting Passengers, volume I and II, Railway Transportation. Field research included on-site cartography and a photo archive of most of Bucharest's factories. In order to improve the quality of the study, a historical analysis of the capital's industry was undertaken, at the Bucharest subsidiary of the Romanian State Archive.

The old city plans, such as the 1852 (Planul Bukurestului Ridikat, tras chi publikat din porunka prea inaltzatului domn stăpânitor Barbu Dimitrie Stirbeiu de Maior Baron Rudolf Artur Borroczyn / The Plan of the Lifted Bucharest, transcribed through the wich of the high lord Barbu Dimitrie Stirbeiu by the Major Baron Rudolf Artur Borroczyn), 1871 (Bcuresci Capitala Romaniei, Major D. Pappasoglu / Bucuresci, the Capital of Romania, by Major D. Pappasoglu), 1911 (Planul orașului București, Ediția oficială / Bucharest City Plan, the Official Edition), 1923 (Ghidul Pântea / Pântea Guide), 1938 (Împărțirea capitalei pe sectoare comuna, poștale și de poliție / Dividing the capital by communal, postal and police sectors), 1943 (Împrejurimile Bucureștiului întocmit de general C-tin Teodorescu I Bucharest Surroundings compiled by the General C-tin Teodorescu), were georeferenced in a GIS program. Because the mentioned city plans didn't have a system of coordinates they were georeferenced by using the image to image function which works by attributing coordinates by finding common points on an already georeferenciated map, in our case Google Maps.

A document that shows the spatial distribution of Bucharest's industry at the beginning of last century is the 1928 Industrial Plan, which is useful in analysing the dynamic of the industrial landscape in Bucharest. On it, there are located most of the factories, workshops and micro-workshops of that year. They are represented by different coloured squares with adjacent numbers that correspond to the description on a list attached to the plan. All these squares were introduced by creating a layer in GIS, also, the list was introduced in a spreadsheet and saved as a .dbf format in order to join the corresponding squares with the features included on the list. As such, at any given time, information is available about what factory was located in a specific location, its type as well as status, as well as the status of that parcel of land on other plans from other time periods.

\section{The transition of Bucharest's industry}

In a 1931 book, called The 1881-1931 Semicentenary - The History of Technical Development in Romania, volumes II and III, edited by the Romanian Politechnical Society, Constantin D. Buşilă, the president of the General Union of Industrialists in Romania (UGIR after its Romanian), said that before 1881 there was no industry of any kind in Romania. Exceptions to this, where found in Bucharest in the form of the Solacolu pasta factory (1828), the Assan Mill (1853), the Lemaître Metallurgical Factory (1864), the Max Tonolla systematic bricks factory (1865), the Cotroceni basalt and ceramic factory (1865) 
which after the First World War was turned into a rubber and chemicals factory. We should also name the D. Staicovici preserves factory (1874), the Chitila sugar factory (1878), the Matches factory (1879), and the

Giurescu (1966) argues that the shift from small workshops to the first factories took place in Bucharest after 1848. The first factories in Bucharest were military in nature: the Army Arsenal in Dealu Spirii (1861), extended over several stages, Pirotehnia and Pulberăria, located in western Bucharest towards Cotroceni. The industrial development of Bucharest at the end of the 19th century and the beginning of the 20th century was based on such units, their appearance being an economic necessity. In addition, at this point in time, the first legislative measures, sustaining the national industry were implemented. For example, in 1887, Parliament voted the Law for the Protection of National Industry that granted a series of fiscal and tariff advantages to companies with a capital of minimum 50.000 lei and 25 employees, and as such lead to the implementation and development of small workshops by improving their technical features and increasing their staff. Out of the 115 industrial companies existing in 1893, 102 benefited from the law and in 1902 this number rose to 178 (Giurescu, 1966). In this time span factories relating to the food industry opened, such as the Bragadiru Beer Factory (1894), preserves factories at Staicovici and Știrbei (in Buftea), mills and systematic bakeries, distilleries, vegetable oil factories like Assan and Hermes. In terms of metallurgical industry, older companies like Lemaître (set up in 1864 as a small mechanical laundry with Belgian capital), Rășcanu (1890, foundry), M. Botez (1901, tinware shop) and Wolf, extended their activities.

An industry without a specific location in Bucharest was the building materials industry. Herbst (1971) declared that its development took place especially between the two world wars (1920-1940). For this period of time, he mentions the appearance of a series of tiles and cement factories (i.e. Titan Factory), cardboard factories, asphalt, terracotta, and so on. This branch was comprised, especially by small factories with only a few of them having permanent activity and the rest activating only seasonally. The brick factories were located around Bucharest, in Băneasa, Colentina, Fundeni, Cățelu, and DudeștiCioplea.

In the same time frame, textile and leather factories were build. An important example were Alexandrescu (1885) and Prodanof (1888), located in the south-east of the city which opened as a result of an 1885 law that stipulated tax exemptions for foreign brought tanning substances (Giurescu, 1966). In 1938, there were 150 companies activating in light industry in Bucharest, with most of them being textile factories the majority of which had a complex profile or being silk weaving factories. The weaving factories functioned based on the import of semi-products, especially cotton. After 1948, the existing factories and workshops concentrated into a smaller number of enterprises (Herbst, 1971:268).

We previously mentioned that some of the factories developed greatly, because of state contracts or of custom protection measures from similar competing foreign products. However, there were also periods when some administrative decisions tried to limit some of these instances of "favouritism". When that happened, the leadership of a company would react immediately and 
draw up complaints to the authorities in which they would inform them, that, if the measures will be sustained/continued they would have to reduce their activity and insist on the social outcome, in the form of the massive layoffs they would have to conduct. In order to protect their economic interests the foundries and metallurgic plants in Bucharest and Ploiești, among which Vulcan, Wolf, and Lemaître established, in 1912, an association that act as a "prior to a definite agreement on setting prices", but they avoided it being seen as a monopoly type of the respective factories.

\section{Micro-regional Bucharest industries}

Based on cartographic documents and field research the authors defined nine industrial areas in Bucharest for the time span between the 90s and present day. The determined spatial structures emphasize, sometimes, the relationships between their components, respectively that in a specific area more than one industrial activity, functionally integrated, existed, or, that would allow the use of both male and female workforce, located in the proximity of neighbourhoods connected to certain factories.

This industrial development lead to the delineation of industrial regions or areas in Bucharest. This consist of dividing some areas apart from others based on one or multiple characteristics they share. This study will describe the areas that once existed in Bucharest in the pre-socialist period but will also present a series of areas of the city that have lost their industrial functions. The latter cases were caused by simply shutting down of factories or their size not being appropriate to their nomenclature anymore, as was the case of small smithies or leather workshops. In other areas the industrial buildings disappeared because of the systematization works, as was the case of the civic city center or the Piața Victoriei- Piața Presei Libere northen area of Bucharest.

As Herbs (1971) notes, the geographical allotment of Bucharest's industry, at the end of the 19th century, had two diametrically opposed features: on one hand there was a clear intent to locate as many industrial companies in a relatively small geographical area, and on the other, one could observe a dispersion of activities in the available area, especially of small workshops, but also some factories. Two geographical areas were distinctly traced: Dâmboviţa Valley, in the Șerban Vodă Bridge - Abator Str. area, which was the location of the most important tanneries in the city, the Communal Abattoir and the Lemaître factory as well as other workshops; the Ștefan cel Mare and Colentina Roads, where numerous mills, oil presses, the Stela soup factory, mechanical workshops, and food workshops were located. Vintilă Mihăilescu (2003) stipulates that Bucharest's industrial areas extended from the former ring roads (Grozăvești, Orhideelor, Titulescu, Iancu de Hunedoara, Ștefan cel Mare, Mihai Bravu) towards the ring roads of the old forts and their tentacular axis followed the radial major street networks. Only the Filaret and Tăbăcari sectors remained inside this line (Panduri Road, Tudor Vladimirescu Avenue, Viilor Road, Șerban Vodă Road, Lânăriei Street, Laborator Street), the first one all the way up to Spirei Hill, and the latter one up to the Radu Vodă Hill. 
The Dâmbovita Valley industrial area saw the emergence of manufacturing workshops from the first half of the 18th century (Figure 1). Their positioning depended on their profile and this area was abundant in activities that need a lot of water such as tanneries, saddleries, soap factories, candle-making workshops. On the Borroczyn plan from 1852, an area called Kărămidari appeared, surrounded by vegetable gardens and two mills, one of them called Foicharu.

On the next city plan, from 1871, the industrial references multiply together with a specific street names, born out of the general tendency of concentrating certain types of activities and manufactories in particular slums and on particular alleys inside the city: (Str. Tabacilor, Str. Tabaci- both related to tobacco, Str. Morilor - related to mills, Lânari - related to wool, Aurari- related to gold smiths), a church (Cărămidaru - related to brick making), and two more



Figure 1. Dâmbovita Valley

Source: Pappasoglu, M. D. (1871). Bucuresci Capitala Romaniei. 
important factories, one called Abatoriu (located on Văcăreşti Road, close to a "Zaara", probably an archaic version of "zaherea" - a food ration given to animals made out of bran, sugar beets and salt), and close to it a laundry service on the spot of the future Timpuri Noi factory. Light industry activities remained predominant in Bucharest as far as the 1911 plan went as well, this year seeing the addition of the Bourulleather factory and also the 1923 plan when the T. Sapat files factory, Gr. Alexandrescu leather factory, the Cotton Factory and the STB Lânăriei depot were added. The most important landmark of this area was the Lemaître factory, one of the oldest industrial units in Bucharest. The Louis Lemaître opened it, in 1864, as an automated laundry service for hospitals. It became a metallurgical factory in 1869, when the first iron foundry in the country was commissioned (Iordănescu, Georgescu, 1986). For this change in profile, he needed to build a new $3 \mathrm{~km}$ long garage, so he bought $44.000 \mathrm{~m} 2$ on Lânăriei St. where he built a carriages factory.

The Filaret Train Station - Rahova industrial area is located around Filaret Station, which then extended towards the west and a prime factor that contributed to the development of the industry in the capital was the construction of the railway (Figure 2). The first train station in Bucharest was Filaret, opened in 1869 and the second one was the Târgoviștei Station, currently the North Train Station, opened in 1872. At the end of 1872 these stations were connected through a transit line which also included Cotroceni Halt and Dealu Spirei Station. The Obor Station (East) became operational, in 1923. Once the railway network became functional, it influenced the location of factories and plants.

The Filaret Station was the first to open in Bucharest. It was envisioned as a terminal station, with its headquarters being a U-shaped building. This station connected Bucharest with the closest Danubian port, Giurgiu. This connection showed just how important the river was at the time. The railway works began with severe legislative difficulties, because of the parliamentarians of the time hesitated to decide the best connection destination with Bucharest but the leader of the country, Alexandru Ioan Cuza insisted that the railway connection would be with the Danube, via Giurgiu. The inauguration of this line was done at 19/31 October 1869, although it was serviceable since august. After the construction in 1872 of the Târgoviștei Train Station, the nowadays North Station, the importance of Filaret Station declined, presenting only local interest as of 1895 , and even in 1879 "whoever wanted to expressly travel along the Danube would take the train to Giurgiu, as it was faster to get to the West by traveling to Vârciorova or Predeal" (Iordănescu, Georgescu, 1986:330). On November 19, 1960, the Filaret Trains Station finally closed to railway traffic, and transformed into a bus station.

The E. Wolf car factory opened in 1876, as a small workshop on its present location in Filaret, (Bușilă, 1931), and, in its first years, produced warheads for the War Ministry. According to the Wolf S.A.R. History, found at the State Archives - Bucharest Subsidiary, the factory was constructed by Erhard Wolf, a Swiss citizen, who settled down in the country in 1877, after being an attaché to the Russian general headquarters as a bandages supplier during the Romanian - Turkish war. Because the Army Arsenal decided to produce its own warheads, after buying the special machineries that E. Wolf had especially brought from aboard of him, he had to start manufacturing other products. 




Figure 2. Map of Filaret Train Station - Gara de Nord Train Station

Source: Pântea, M. (1923). Planul si Ghidul Orasului Bucuresti

In November 1924, in a letter addressed to the authorities, E. Wolf signalled a few problems that his factory was facing, while also describing the activities it had had at the time. In order to be able to continue its activities in Filaret and Constanţa, he was soliciting the state to adopt a series of emergencies measures: establishment of protective import tariffs for the local industry in order to combat dumping from the foreign competition. He drew attention to the fact that the Romanian tax on metallurgical products was of 13-18\%, compared to other states where it was higher (Germany 20-25\%, Austria and Hungary 25$30 \%$, USA $30-50 \%)$.

The Bucharest Customs Warehouses was located close to the Bragadiru Beer Factory, and was designed by the architect Giulio Magni. Its construction began 


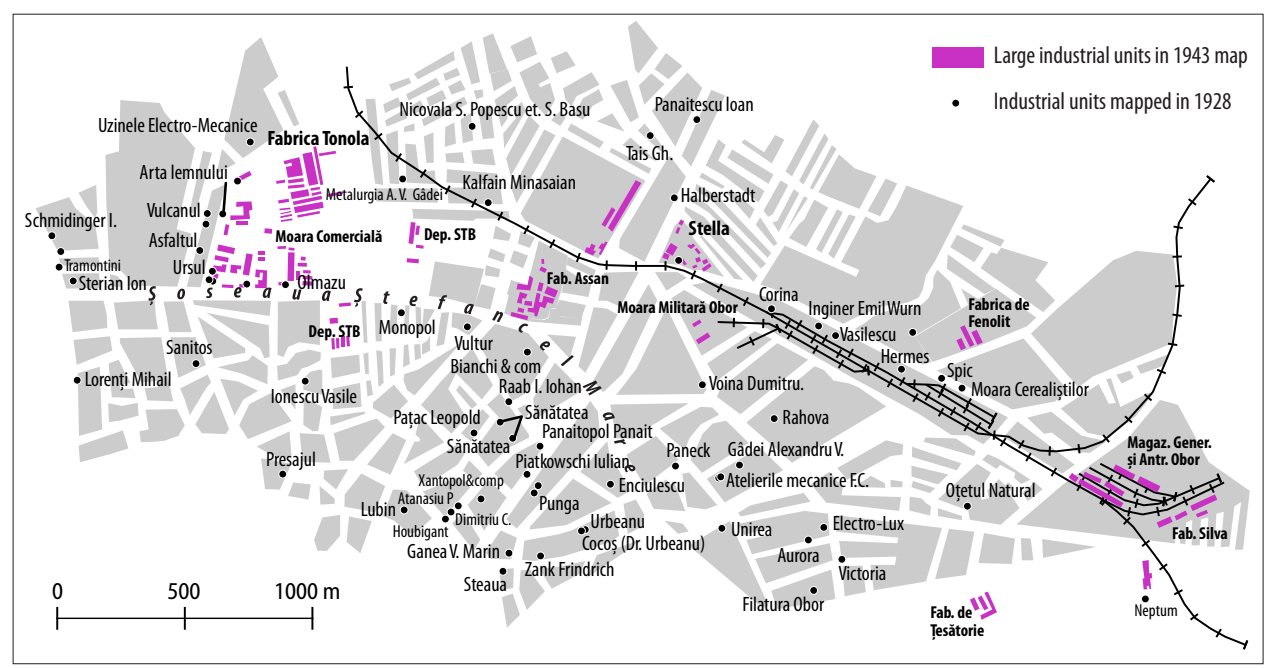

Figure 3. Eastern industrial area

Source: Authors compilation from: Teodorescu, C.-t. (1943). Harta „Bucureşti si împrejurimile”; Planul industrial al orasului Bucuresti (1928).

in 1894 and it was part of the first city-modernization programs, which also included building the Commodities Exchange, an administrative building, four warehouses, and one of the first water towers in Romania.

The North Train Station - Grozăvești - Politehnica industrial area. The first factories were food related, as well as military profile, through clothes manufactories, barracks and ammunitions. The second train station in Bucharest was Târgoviște, opened in 1/13 September 1872, when the RomanGalați-București-Pitești railway line was given into operation. The works for this line began at 10/22 September 1869. After only three months since its official inauguration, at 13 December 1872, it was connected to the Filaret train station with an internal line that also passed through Cotroceni halt and Dealu Spirii Station. The train station is an U-shaped building, built between 1868 and 1872, and was designed as a terminus destination, similar in concept with those in Vienna, Berlin, Budapest, or Toronto meant to be as much as possible part of the city but avoiding large expropriations.

The Eastern industrial area appeared, after 1920, directly related with the construction of the Eastern Train Station and the railway connection with Pantelimon $(6 \mathrm{~km})$, in 1932, as well as the lower land costs/prices (Figure 3). It included automotive industries, metalworking, as well as textile, leather and chemical industries. The Assan factories were built between 1853 and 1948. At first, they only consisted of a small man-powered oil press and a few horsepowered grain-grinding stones. George Assan (the father) replaced these with a thermic - powered mill, whose construction he began in 1853. It was the first factory in the country powered by the 7 tons steam boiler. It had to be labouriously transported for four weeks from Giurgiu to Bucharest, after being brought from Vienna to Giurgiu on the Danube in only two weeks. The dust road from Giurgiu to Bucharest was in precarious shape, and consolidation had to be made to all the bridges and footbridges that the boiler was going to cross. In 1894, George Assan added a new paints and varnishes section to his factory. 
Giurescu (1966) shows that a steam boiler powered mill was long overdue in Bucharest partly because of its growing population and because in wintertime the Dâmboviţa and Colentina rivers would freeze and water-powered mill would stop working.

\section{Conclusions}

The development of Bucharest in the context of the political events that marked the world at the beginning of the 20th century was based on its industrial development. Bucharest's industry is mostly associated with the socialist period, as the specialized literature is scarce in references that predate this moment. Bucharest's industrial construction after the war was done on the old spatial configuration of the industrial landscape whose genesis was marked by the development of the transport infrastructure and by the administrative reforms and governmental decisions.

The emergence and development of Bucharest's industries was done simultaneously with the construction of the railway system and the terminus stations as a direct consequence of the infrastructure public policies of the state. The state's support materialized through subsidies, lead to an increase in the number of factories and workshops and the growing necessities of a city confronted with a demographic growth expanded the variety of existing enterprises.

The industrial development in Bucharest at the end of the 19th century and the beginning of the 20th happened as an economic necessity, marked by an absence of such units. The first industrial units had a military profile and emerged as a direct consequence of Romania's position at the end of the 20th century, respectively it entering the war in order to gain its independence. The new status of the country, after gaining its independence created the premises for modernizing and implicitly developing small industries across the city, which even at that time was the capital of the newly formed country.

This kind of analysis is might be a starting point for understanding the regional industrial context. Planning future industrial areas should be done after understanding similar past evolutions. Clarifying the problems and territorial changes created by the emergence of regional industrial structures in the past can optimize the present political decisions about urban planning. In the future, a quantitative analysis of the evolution of the industrial landscape can serve as a stepping stone for seeing the way in which this type of landscape can influence the functional fragmentation of an urban scene. Historical GIS can answer a series of questions about the dynamic of quantitative aspects of industrial landscapes and the degree in which it influences urban areas in general.

\section{References}

Borroczyn, R. (1852). Planul Bukurestului Ridikat, tras chi publikat din porunka prea inaltzatului domn stăpânitor Barbu Dimitrie Stirbeiu.

Giurescu, C. (1966). Istoria Bucureștilor din cele mai vechi timpuri până în zilele noastre. București, România: Editura Pentru Literatură. 


\section{Gabriel Simion et al.}

Gregory, I. (2002). Time variant databases of changing historical administrative boundaries: a European comparison. Transactions in GIS 6, 161-78.

Gregory, I., Bennett, C., Gilham, V., \& Southall, H. (2002). The Great Britain Historical GIS Project: from maps to changing human geography. Cartographic Journal 39, 37-49.

Greogory, I., \& Healey, R. (2007). Historical GIS: structuring, mapping and analysing geographies of the past. Progress in Human Geography 31(5), 638-53.

Healey, R., \& Stamp, T. (2000). Historical GIS as a foundation for the analysis of regional economic growth. Social Science History 24, 575-612.

Herbst, M. (1971). Geografia industriei municipiului București. Cluj-Napoca, România: Teză de Doctorat, Universitatea Babeş-Bolyai.

Holdsworth, D. (2003). Historical geography: new ways of imaging and seeing the past. Progress in Human Geography 27, 486-93.

Iordănescu, D., Georgescu, C. (1986), Construcții pentru transporturi în România, vol. 1-2, Centrala de Construcții Căi Ferate, București

Istoricul desvoltării tecnice în România. (1931). Semicentenarul Societăţii Politehnice 18811931. București, România: Bululetinul Societății Politehnice 1931.

Împărțirea capitalei pe sectoare comuna, poștale și de poliție. (1938). București, România.

Knowles, A. (2005). Emerging Trends in Historical GIS. Historical Geography 33, 7-13.

Knowles, A. (2008). Placing History: How Maps, Spatial Data, and GIS are Changing Historical Scolarship. New York, United States of AmericaE: Esri Press.

Knowles, A., \& Healey, R. (2006). Geography, timing and technology: a GIS-based analysis of Pennsylvania's iron industry, 1825-187. Journal of Economic History 66, 608-34.

MacEachren, A., Wachowicz, M., Edsall, R., Haug, D., \& Masters, R. (1999). Constructing knowledge from multivariate spatiotemporal data: integrating geographical visualization with knowledge discovery in database methods. International Journal of Geographical Information Science 13, 311-34.

Mihăilescu, V. (2003), Evoluția geografică a unui oraș - București. București, România: Paideia.

Monografia RATB (1909-1998), Regia Autonomã de Transport București.

Pappasoglu, M. D. (1871). Bcuresci Capitala Romaniei.

Pântea, M. (1923). Planul și Ghidul Oraşului București. București, România.

Planul industrial al oraşului București. (1928). București, România: Ministerul Industriei și Comerțului, Editura Bibliotecei Științelor Popularizate.

Planul Orașului București. (1911). București, România: Serviciul Geografic al Armatei.

Siebert, L. (2000). Using GIS to document, visualize and interpret Tokyo's spatial history. Social Science History 24, 537-74.

Southall, H. (2006). A vision of Britain through time: making sense of 200 years of census reports. Local Population Studies 76, 74-86.

Teodorescu, C.-t. (1943). Hartă „Bucureşti și împrejurimile”.

URTP (Uniunea Românã de Transport Public) (1998), Transportul public de suprafaţă din Municipiul București (1871-1998).

Wright, D., Goodchild, M., \& Proctor, J. (1997). Demystifying the persistent ambiguity of GIS as 'tool' versus 'science'. Annals of the Association of American Geographers 8, 346-62. 